\title{
情報科学の展開と DDS
}

橋田充

近年, ゲノム医学が次世代創薬の 基盤として広く認知されるととも に, コンピナトリアルケミストリー (CC)による化合物ライブラリーの 構築や薬効・動態の迅速評価を目的 とするハイスループットスクリーニ ング(HTS)に代表される新薬開発 の新しい戦略, 方法論が急速に発展 している, 一方, 医薬品候補化合物 の選択以後の開発プロセスあるいは 臨床使用においては, 最終目的であ る薬物治療の最適化を実現するため に, 薬物体内動態の精密制御, 至適 化を可能とする高機能化された新し いDDS 技術の開発, 導入が不可欠 と考えられ,こうした観点から DDS はゲノム創薬技術, CC や HTS とと もに未来の薬物治療, 創薬を支える 最も重要な基盤技術の一つと位置つ けられている。

新規性, 独創性の高い DDS の開 発は, 疾患に対する分子生物学情報 やバイオテクノロジー(BT)の集 約, 動態のモデル解析手法やコン ピュー夕制御など情報科学技術 (IT)の導入, あるいはインテリジェ ント材料・ナノテクノロジー(NT) の開発など, きわめて学際, 学融的 な科学技術の統合のもとに可能とな る. 新しい千年紀を迎えて, 人類の 直面する課題に応え新しい産業を生 み出すことを目的に, 政府が推進し たミレニアム・プロジェクトをはじ め, BT, IT, NT を代表的なキー ワードとして現在関連各領域で進め られている先端的な研究プロジェク トの多くは, 将来のDDS 研究の発

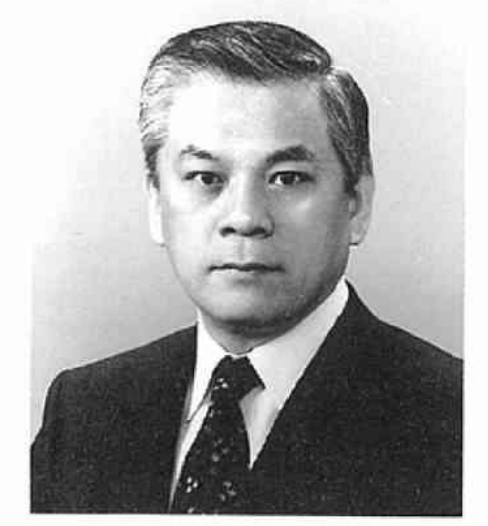

はしだ みつる 京都大学大学院菜学研究科

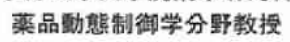

展にも直接あるいは間接的に大きく
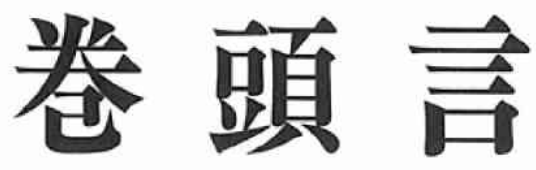

DDS 18 巻 1 号 平成 15 年 貢献することが期待されている. 実 際に, 情報化, 高榆化に対応した革 新的医療, ヒトゲノム解析などにお いて, DDS 技術, あるいは再生医学, 遺伝子治療, 生体シミュレーション などDDS と関連の深い研究が, 先 端医学研究の中心課題としてプロ ジェクトの柱となっている.

DDS 研究の将来像を俯瞰するた めには, 国際的な視点に基づく技術 動向の考察も重要である.ゲノム創 薬, CC, HTS など上記先端創薬基盤 技術の多くは諸外国で生まれ，わが 国の医薬品産業においては技術導入 に追われる感が強いが，そのなかで DDS は基䃈, 応用研究の両面におい て, 日本が現実に重要な役割を果た している貴重な領域とされる。わが 国の DDS 研究は, 医学, 薬学, 工学, 理学, 農学など, きわめて広範な研 究領域の有機的結合を特徵とし, 日 本DDS 学会がそのプラットホーム を提供している.

DDS は, 物質動態の視点より生体 をシステムと捉え, その特性の解析 を通じて薬物動態の制御を目指す技 術体系である，本巻の特集 “情報科 学の展開とDDS”では, 情報科学を キーワードとして時代を斬る視点か ら, DDS 研究の最新動向が紹介され ているが,これは同時にDDSの将 来像を探る試みでもある. “DDS と BT, IT, NT”を主題とする第 19 回 日本DDS 学会大会とあわせて, 新 しい時代の予感を得る機会となれば 幸いである。 